\title{
Anthracnose of Prairie Gentian and Loquat Caused by Colletotrichum acutatum*
}

\author{
Toyozo SATO**, Seiji Uematsu***, Hitomi MizoGuCHI', \\ Tamotsu KIKU ${ }^{H+}$ and Takeo MIURA ${ }^{\text {It+ }}$
}

Key words : anthracnose, Colletotrichum acutatum, Colletotrichum gloeosporioides, Eustoma grandiflorum, Eriobotrya japonica.

Severe anthracnose of prairie gentian (Eustoma grandiflorum (Raf.) Shinn., synonym: E. russellianun (Hook.) G. Don ex Sweet) first occurred in Chiba and Miyazaki Prefectures in 1985 and 1991, respectively. A species of Colletotrichum unknown in Japan at that time was isolated from diseased plants in both locations. On the other hand, fruit rot of loquat (Eriobotrya japonica Lindley) has long been known to be caused by Colletotrichum gloeosporioides (Penzig) Penzig et Saccardo (synonym: Gloeosporium eriobotryae Spegazzini) and some other fungi ${ }^{6,7)}$. Another species of Colletotrichum was isolated from rotten fruits of loquat in Chiba Pref. from 1987 to 1993 and in Kagoshima Pref. in 1990. The fungi isolated from both plants were morphologically similar to one another, but obviously different from descriptions of $C$. gloeosporioides ${ }^{1,14)}$. Therefore, we identified the isolates in detail and carried out inoculation experiments with them.

Anthracnose of prairie gentian Small, ellipsoid and light brown lesions appeared first on stems and occasionally on leaves. The lesions enlarged and bore numbers of concentrically arranged arcervuli with rose to orange conidial masses (Plate I-1). The lesions often developed at nodes in immature plant parts. When stems were girdled by lesions, upper parts became wilted and blighted (Plate I-2). The acervuli were subepidermal, $0.05-1.5 \mathrm{~mm}$ in diameter and lacked setae (Plate I-3). Conidiophores were cylindrical to obclavate, straight or slightly curved, hyaline, 10-24 $\mu \mathrm{m}$ in length and 2.8-3.2 $\mu \mathrm{m}$ in width. Conidia were aseptate, hyaline, allantoid, fusiform or cylindrical with acute or rounded ends, varied in shape even within an isolate (Plate I.4), and measured $6-16.5(-22) \times 2-4.5(-6.5) \mu \mathrm{m}$. Terminal appressoria formed on hyphae in slide cultures of potato carrot agar (PCA). The appressoria were one-celled, pale grayish brown, obovoid to pyriform, not lobed (Plate I-5) and $6-11 \times 4.2-6(-7.5) \mu \mathrm{m}$ in size. Materials from Chiba and Miyazaki were morphologically similar to one another (Table 1).

Colonies of both Chiba and Miyazaki isolates on potato dextrose agar (PDA) plates were white at first, but some later became dark brown (e.g. MAFF306251), or reddish brown (e.g. MAFF306252) (Plate I-6). Both isolates produced abundant conidia. They could grow at $5-33^{\circ} \mathrm{C}$ on PDA plates, with optimum growth between 26 and $28^{\circ} \mathrm{C}$ (Fig. 1). Characteristics of the isolates in culture and on the host were consistent with previous descriptions of Colletotrichum acutatum Simmonds ex Simmonds ${ }^{2,3,9,11,13,14)}$ (Table 1).

Thirteen cultivars of prairie gentian (Azuma-no-nami, Azuma-no-fuji, Azuma-no-yuki, Azuma-no-asa, Azumano-yosooi, $F_{1}$ Royal pink, Holy red, King of blue picotee, Kiri-no-mine, Miyako-shiro, Shisen, Wakamurasaki and Yama-no-momo) were inoculated by spraying with a conidial suspension $\left(8 \times 10^{7}\right.$ conidia $\left./ \mathrm{ml}\right)$ of MAFF 306252 . Inoculated plants were covered with plastic bags for 17 $\mathrm{hr}$. The symptoms were reproduced on stems of all cultivars inoculated and on leaves of $F_{1}$ Royal pink. A fungus identical to the inoculum was reisolated from every diseased cultivar. As far as we know, Colletotrichum acutatum has not previously been reported to cause disease on this flowering crop plant. We propose to call this new disease anthracnose of prairie gentian.

Anthracnose of loquat Some of the loquat fruits harvested in Chiba Prefecture had sunken, dark brown lesions on their basal or lateral parts. Rose pink to brownish orange conidial masses appeared on the lesion 3 to 5 days after keeping them in tall petri dishes (Plate

* An outline of this paper was presented at the Annual Meetings of the Phytopathological Society of Japan, $1992^{10)}$ and 1994'12).

** Shikoku National Agricultural Experiment Station, Zentsuji 765, Japan＼cjkstart四国農業試験場

*** Chiba Prefectural Horticultural Experiment Station, Yamamoto, Tateyama 294, Japan 千葉県暖地園芸試験場

- Miyazaki Prefectural Government Higashiusuki-hokubu Agricultural Extention Center, Nishishina 1, Nobeoka 882, Japan＼cjkstart東臼杵北部農業改良普及センター

" Kagoshima Prefectural College of Agriculture, Honjo, Tarumizu 892-21, Japan＼cjkstart鹿児島県立農業大学校

${ }^{\prime \prime}$ Miyazaki Prefectural Government Agricultural Extention Service, Tachibanadori-higashi 2, Miyazaki 880, Japan 崎県農政水産部営農指導課 
Table 1. Morphological comparison among pathogens of prairie gentian and loquat anthracnose, Colletotrichum acutatum and Colletotrichum gloeosporioides previously reported

\begin{tabular}{|c|c|c|c|c|}
\hline \multirow{2}{*}{ Host plant } & \multirow{2}{*}{ Location } & \multicolumn{2}{|c|}{ Morphology and measurement of } & \multirow{2}{*}{ Literature } \\
\hline & & Conidium & Appressorium $^{\text {a) }}$ & \\
\hline $\begin{array}{l}\text { Prairie gentian } \\
\text { (Eustoma } \\
\quad \text { grandiflorum) }\end{array}$ & $\begin{array}{l}\text { Chiba } \\
\text { Miyazaki } \\
\quad \text { (total: }\end{array}$ & $\begin{array}{l}\text { ellipsoid, fusiform, } \\
\text { acute or round both ends } \\
8-16.5 \times 2-4.5 \mu \mathrm{m} \\
6-16(-22) \times 2-4.5(-6.5) \mu \mathrm{m} \\
6-16.5(-22) \times 2-4.5(-6.5) \mu \mathrm{m}\end{array}$ & $\begin{array}{l}\text { obovoid, ellipsoid, } \\
\text { clavate or pyriform } \\
5.8-10.5 \times 4.5-6 \mu \mathrm{m} \\
6-11 \times 4.2-6(-7.5) \mu \mathrm{m} \\
6-11 \times 4.2-6(-7.5) \mu \mathrm{m}\end{array}$ & $\begin{array}{l}\text { (the present authors) } \\
\text { Sato et al. }(1992)^{101} \text { ) }\end{array}$ \\
\hline $\begin{array}{l}\text { Loquat } \\
\text { (Eriobotrya } \\
\text { japonica) }\end{array}$ & $\begin{array}{l}\text { Chiba } \\
\text { Kagoshima } \\
\quad \text { (total: } \\
\text { Shizuoka } \\
\text { Kagoshima }\end{array}$ & $\begin{array}{l}\text { ellipsoid, fusiform, } \\
\text { acute or round both ends } \\
9-16.4(-20.4) \times 3-5.6 \mu \mathrm{m} \\
6-15.5 \times 3-5 \mu \mathrm{m} \\
6-16.4(-20.4) \times 3-5.6 \mu \mathrm{m} \\
8-14 \times 3.6-5.6 \mu \mathrm{m} \\
14-17 \times 5-7 \mu \mathrm{m}\end{array}$ & $\begin{array}{l}\text { obovoid, ellipsoid, } \\
\text { clavate or pyriform } \\
6-10.4 \times 4.4-7.2 \mu \mathrm{m} \\
6-11.2 \times 4.4-8 \mu \mathrm{m} \\
6-11.2 \times 4.4-8 \mu \mathrm{m} \\
\text { (no datum) } \\
\text { (no datum) }\end{array}$ & $\begin{array}{l}\text { (the present authors) } \\
\left.\text { Sato et al. }(1994)^{121}\right) \\
\text { Hemmi }(1920)^{4)} \\
\text { Naito }(1937)^{8)}\end{array}$ \\
\hline $\begin{array}{l}\text { (C. acutatum) } \\
\text { various } \\
\text { various } \\
\text { Strawberry } \\
\text { Anemone } \\
\text { Prune }\end{array}$ & $\begin{array}{l}\text { Australia } \\
\text { Oceania } \\
\text { Tochigi } \\
\text { Ehime, Shizuoka } \\
\text { Nagano, Okayama }\end{array}$ & $\begin{array}{l}\text { fusiform, acute both ends } \\
8.3-14.4 \times 2.5-4 \mu \mathrm{m} \\
8.5-16.5 \times 2.5-4 \mu \mathrm{m} \\
8.9-17 \times 3.2-4.9 \mu \mathrm{m} \\
8-14.4(-17) \times 2.4-5.6 \mu \mathrm{m} \\
7.6-16(-21) \times 3-5.2 \mu \mathrm{m}\end{array}$ & 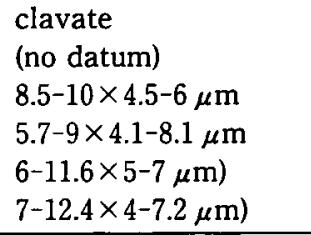 & $\begin{array}{l}\text { Simmonds }(1965)^{13)} \\
\text { Sutton }(1980)^{14)} \\
\text { Ishikawa et al. }(1992)^{5)} \\
\text { Sato et al. }(1996)^{11)} \\
\text { Sato et al. }(1996)^{11} \\
\end{array}$ \\
\hline $\begin{array}{l}\text { (C. gloeosporioides) } \\
\text { various }\end{array}$ & various & $\begin{array}{l}\text { obtuse at the apex } \\
9-24 \times 3-4.5 \mu \mathrm{m}\end{array}$ & $\begin{array}{l}\text { clavate or irregular } \\
6-20 \times 4-12 \mu \mathrm{m}\end{array}$ & Sutton $(1980)^{14)}$ \\
\hline
\end{tabular}

a) produced from hyphae in slide cultures with PCA at $20-25^{\circ} \mathrm{C}$.

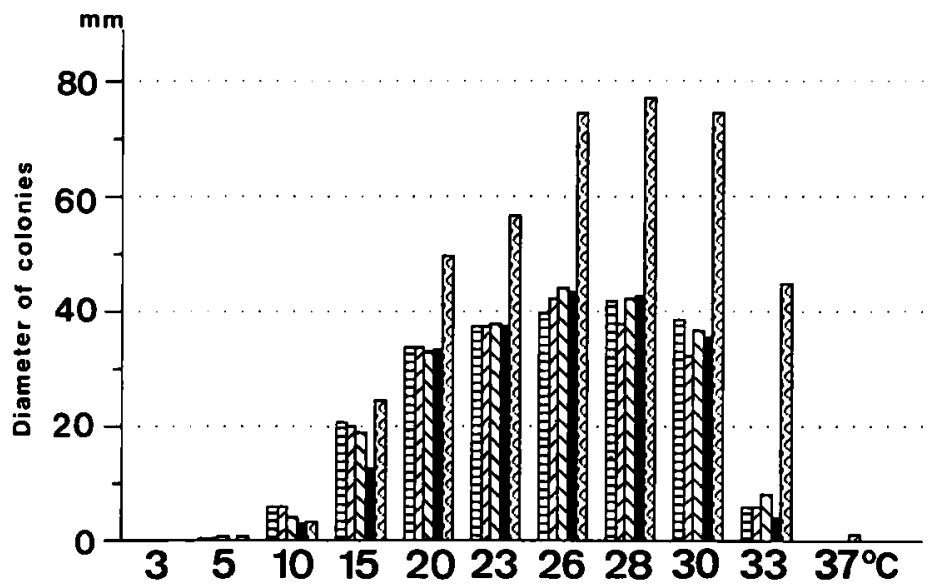

Fig. 1. Mycelial growth of Colletotrichum acutatum (isolated from prairie gentian and loquat) and Colletotrichum gloeosporioides (Glomerella cingulata) under various temperatures. The histogram indicates diameter of colonies after culturing on PDA plates of $90 \mathrm{~mm}$ diam. for 5 days in darkness. from prairie gentian in Chiba Pref., WIJD C. acutatum (MAFF 306253) isolated from prairie gentian in Miyazaki Pref., $\mathrm{MUIV}$ C. acutatum (average of MAFF305596, MAFF306404, MAFF306405, MAFF306406 and MAFF306407) isolated from loquat in Chiba Pref., $C$. acutatum (average of MAFF306409 and MAFF306410) isolated from loquat in Kagoshima Pref.,

I-7). The symptoms and signs on fruits were almost the same as those described for the loquat anthracnose previously in Japan ${ }^{7)}$. In Kagoshima, heart rot and lesions near the calyx were also observed on ripe fruits attacked by the disease. The acervuli on the host were not setose, were $0.1-1.2 \mathrm{~mm}$ in diameter, but soon coalesced into larger ones. Single spore isolates of the pathogen were easily obtained from conidial masses on the lesions (Plate I-8). Two types of isolates with different colors were observed among those from Chiba. One was reddish and the other grayish brown. All colonies of the Kagoshima isolates were reddish in color like some Chiba isolates (Plate I-8). Both types of isolates produced conidia abundantly on PDA plates. Few microscopic differences were found between the Chiba and Kagoshima isolates (Table 1). The conidia were 
Table 2. Results of loquat fruit inoculation with Colletotrichum acutatum and Colletotrichum gloeosporioides isolated from various plants (15 days after inoculation)

\begin{tabular}{|c|c|c|c|c|}
\hline \multirow{2}{*}{ Isolate No." } & \multirow{2}{*}{ Isolation source } & \multicolumn{2}{|c|}{ Number of diseased fruits ${ }^{b)}$} & \multirow{2}{*}{$\begin{array}{c}\text { Conidial } \\
\text { formation }\end{array}$} \\
\hline & & Intact & Wounded $^{c)}$ & \\
\hline MAFF305596 & & 5 & 5 & + \\
\hline MAFF306404 & & 0 & 5 & + \\
\hline MAFF306405 & Loquat & 1 & 5 & + \\
\hline MAFF306406 & & 4 & 5 & + \\
\hline MAFF306407 & & 4 & 5 & + \\
\hline MAFF306247 & Prairie & 0 & 5 & + \\
\hline MAFF306253 & gentian & 2 & 5 & + \\
\hline MAFF306283 & Strawberry & 4 & 5 & + \\
\hline MAFF306172 & Sugar apple & 0 & 5 & + \\
\hline MAFF305787 & Papaya & 3 & 5 & - \\
\hline $911003-5^{e)}$ & Apple & 4 & 5 & - \\
\hline
\end{tabular}

a) MAFF with a number of six figures means an accession number of the isolate deposited in the Gene Bank, Ministry of Agriculture, Forestry and Fisheries, Japan.

b) Five intact and five wounded fruits were inoculated with each isolate.

c) Fruits were pricked once with ten bound pins, before inoculation with a suspension of $3 \sim 5 \times 10^{5} \mathrm{conidia} / \mathrm{ml}$ of each isolate.

d) + , abundant; - lacking.

e) C. gloeosporioides, others are all C. acutatum.

aseptate, hyaline, fusiform or ellipsoid, with acute or rounded ends (Plate I-9) and 6-16.4(-20.4) $\times 3-5.6 \mu \mathrm{m}$ in size. Appressoria formed on PCA slide cultures were similar in shape to those of prairie gentian isolates, brown (Plate I-10) and 6-11.2 $\times 4.4-8 \mu \mathrm{m}$ in size.

The optimum, lowest and highest temperatures for growth of both isolates from Chiba and Kagoshima on PDA plates were almost the same as those of the isolates from prairie gentian (Fig. 1), but their growth was slower than those of $C$. gloeosporioides, as reported previously $^{3,5,11-13)}$ (Fig. 1). The morphological and physiological characteristics of the loquat isolates from both prefectures also agreed with those of $C$. acutatum rather than $C$. gloeosporioides ${ }^{3,5,11-14)}$ (Table 1). The pathogen of loquat anthracnose collected by us, therefore, should be identified as $C$. acutatum.

Five intact and five wounded ripe fruits of cultivar Tanaka were inoculated with a conidial suspension (3 $\sim 5 \times 10^{5}$ conidia $/ \mathrm{ml}$ ) of each isolate of $C$. acutatum and C. gloeosporioides listed in Table 2, including loquat isolates. Fruits were wounded by pricking once with ten pins bound together. One drop of the conidial suspension was put on each wound. Fruits inoculated with each isolate were kept in a moist chamber at $25^{\circ} \mathrm{C}$ for 15 days. All wounded fruits showed typical lesions within a week after inoculation. When intact fruits were inoculated, lesions appeared later. The number of diseased fruits varied from 0 to 5 depending on the isolate (Table 2). Conidia were abundantly produced on fruits inoculated with every isolate of $C$. acutatum, but neither of the isolates of $C$. gloeosporioides from papaya and apple formed conidia on the lesions even 15 days after inoculation (Table 2, Plate I-11).

Hemmi $^{4)}$ briefly noted a pathogen of loquat anthrac- nose collected in Shizuoka Pref. for the first time in Japan. He did not mention its scientific name at that time. Nor can we determine its precise identity because he described only the conidia. However, the conidial shape and size which he reported are similar to those of C. acutatum (Table 1). On the other hand, Naito ${ }^{8)}$ identified a pathogen of the disease found in Kagoshima Pref. as Gloeosporium eriobotryae. The species was later treated as a synonym of $C$. gloeosporioides by von $\mathrm{Arx}^{1)}$. Quite recently, a typical $C$. gloeosporioides was isolated from diseased leaves of loquat in Okinawa Pref. ${ }^{9}$ ( $(\mathrm{K}$. Uehara, personal communication). The result of our inoculation experiment lead us to propose that both $C$. acutatum and $C$. gloeosporioides cause loquat anthracnose.

We gratefully acknowledge Dr. A. Kudo, Kuchinotsu Branch of Fruit Tree Research Station, for kindly providing the isolate of $C$. gloeosporioides from apple and for valuable advice about the inoculation experiment of the loquat anthracnose. All fungal isolates examined here were deposited in the Gene Bank, Ministry of Agriculture, Forestry and Fisheries (MAFF), Japan.

\section{Literature cited}

1. Arx, J.A. von. (1957). Die Arten der Gattung Colletotrichum. Phytopathol. Z. $29: 413-468$.

2. Dyko, B.J. and Mordue, J.E.M. (1979). Colletotrichum acutatum. CMI Descriptions of Pathogenic Fungi and Bacteria, No. 630, Commonwealth Mycological Institute, Kew.

3. Gunnell, P.S. and Gubler, W.D. (1992). Taxonomy and morphology of Colletotrichum species pathogenic to strawberry. Mycologia 84 : 157-165. 
4. Hemmi, T. (1920). Beiträge zur Kenntnis der Morphologie und Physiologie der japanischen Gloeosporien. Jour. Coll. Agric. Hokkaido Imp. Univ. Sapporo 9 : 1159, Pl. I -III.

5. Ishikawa, S., Nakayama, K., Tsunemi, J. and Nakazawa, Y. (1992). Strawberry anthracnose caused by Colletotrichum acutatum Simmonds in Tochigi Prefecture. Proc. Kanto-Tosan Pl. Prot. Soc. 39 : 129-133 (in Japanese).

6. Kitajima, H. (1989). Reviews of Studies on Each Fruit Tree Diseases : Loquat Diseases, Yokendo, Tokyo, pp. 522-533 (in Japanese).

7. Naito, T. (1936). Loquat anthracnose occurring in Kagoshima. Ann. Phytopathol. Soc. Jpn. 6 : 180 (abstract in Japanese).

8. Naito, T. (1937). The pathogen of loquat anthracnose, Gloeosporium eriobotryae Speg. (?). Ann. Phytopathol. Soc. Jpn. 7: 65-66 (in Japanese).

9. Sato, T. (1996). Problems of taxonomy and identification of Colletotrichum species. Plant Protection 50 : 273-280 (in Japanese).

10. Sato, T., Mizoguchi, H., Uematsu, S. and Miura, T. (1992). Anthracnose of Eustoma grandiflonum caused by Colletotrichum acutatum. Ann. Phytopathol. Soc. Jpn. $58: 544$ (abstract in Japanese).

11. Sato, T., Ueda, S., Iijima, A. and Tezuka, N. (1996). Reidentification of pathogens of anemone and prune anthracnose. Ann. Phytopathol. Soc. Jpn. 62 : 170-174.

12. Sato, T., Uematsu, S., Kiku, T. and Nakamura, Y. (1994). Anthracnose of loquat caused by Colletotrichum acutatum. Ann. Phytopathol. Soc. Jpn. 60: 339-340 (abstract in Japanese).

13. Simmonds, J.H. (1965). A study of the species of Colletotrichum causing ripe fruit rots in Queensland. Qd. JI. Agric. Anim. Sci. 22 : 437-459.

14. Sutton, B.C. (1980). The Coelomycetes. Fungi Imperfecti with Pycnidia, Acervuli and Stromata : Colletotrichum, Commonwealth Mycological Institute, Kew, pp. 523-537.

\section{和 文 摘 要}

佐藤豊三・植松清次・溝口一美・禧久 保・三浦猛夫：Col . letotrichum acutatum によるトルコギキョウおよぴビワの炭疽 病

千葉, 宮崎両県でトルコギキョウの茎葉に淡褐色, 棈円形の病 斑が生じ,その上に橙色の分生子塊が形成される病害が発生し, 病斑より炭瘨病菌が分離された。また，千葉，鹿児島両県で採集 された腐敗ビワ果実より同様の菌が分離された。分離菌をそれ ぞれの宿主に接種した結果, 病幑が再現され接種菌が再分離さ れた。なお，既報のビワ炭疽病菌 Colletotrichum gloeosporioides を果実に接種した結果, 病斑は出現したが分生子塊は形成され なかった。両分離菌は培地上の生育がやや緩慢で,コロニー董面 が赤色または暗蝎色を帯びた。分生子噟は剛毛を欠き,分生子は 無色, 単細胞, 紡鏵形から長棈円形, 付着器は淡褐色厚膜, 倒卵 形ないし棈円形で全縁であった。以上の特徵より両菌を Colletotrichum acutatum Simmonds ex Simmonds と同定した。 トルコギキョウでは未報告の病害であるため炭疽病と命名し, ビワでは C. acutatum を炭疽病の病原に加えることを提案す る。

(Received October 3, 1996; Accepted October 28, 1996)

\section{Explanation of plate}

Plate I-1-6. Symptoms and pathogen of the prairie gentian anthracnose.

1. A stem lesion bearing acervuli with orange conidial masses.

2. Stem blight occurring above a large lesion.

3. A subepidermal acervulus produced on a stem (cross section, bar : $50 \mu \mathrm{m}$ ).

4. Conidia from a stem lesion collected in Miyazaki Prefecture (bar: $10 \mu \mathrm{m}$ ).

5. An appressorium formed on a PCA slide culture (bar : $10 \mu \mathrm{m}$ ).

6. Colonies of the pathogenic isolates, MAFF306251 (upper), MAFF306252 (lower) cultured on PDA at $25^{\circ} \mathrm{C}$ for 10 days, viewed through bottom of plate.

Plate I-7-11. Symptoms and causal pathogen of the loquat anthracnose.

7. Acervuli and conidial masses on a diseased fruit collected in Chiba Pref.

8. Colonies of pathogenic isolates, MAFF305596 (upper left), MAFF306405 (upper center), MAFF306404 (upper right), MAFF 306410 (lower left) and MAFF306409 (lower right) produced on PDA after culturing at $25^{\circ} \mathrm{C}$ for 20 days, viewed through bottom of plate.

9. Conidia of MAFF305596 isolated in Chiba Pref. (bar : $10 \mu \mathrm{m}$ ).

10. Appressoria of MAFF306405 formed on a PCA slide culture (bar : $10 \mu \mathrm{m}$ ).

11. Lesions on wounded fruits 12 days after inoculation with C. acutatum (MAFF306172, right) and C. gloeosporioides (MAFF305787, left). 


\section{Plate I}

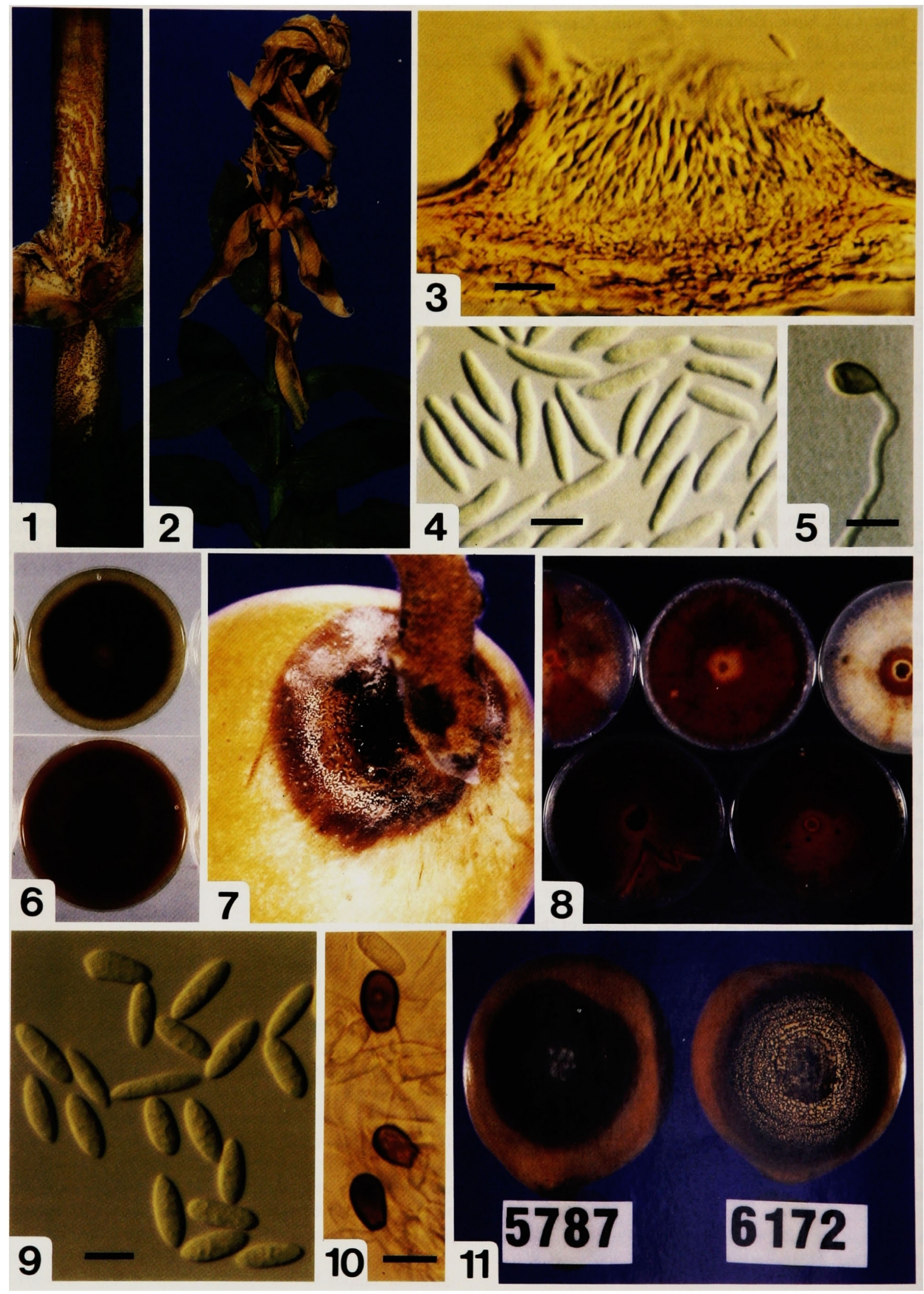

